\title{
BRAF NP_004324.2:p.G469E
}

National Cancer Institute

\section{Source}

National Cancer Institute. BRAFNP 004324.2:p.G469E. NCI Thesaurus. Code C98318.

A change in the amino acid residue at position 469 in the serine/threonine protein kinase

B-raf protein where glycine has been replaced by glutamic acid. 